\section{E-LOGOS}

ELECTRONIC JOURNAL FOR PHILOSOPHY ISSN 1211-0442

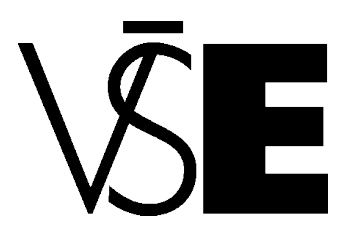

University of Economics

Prague

\title{
O Platónově cestě od Erota k Logu
}

Miroslav Vlček

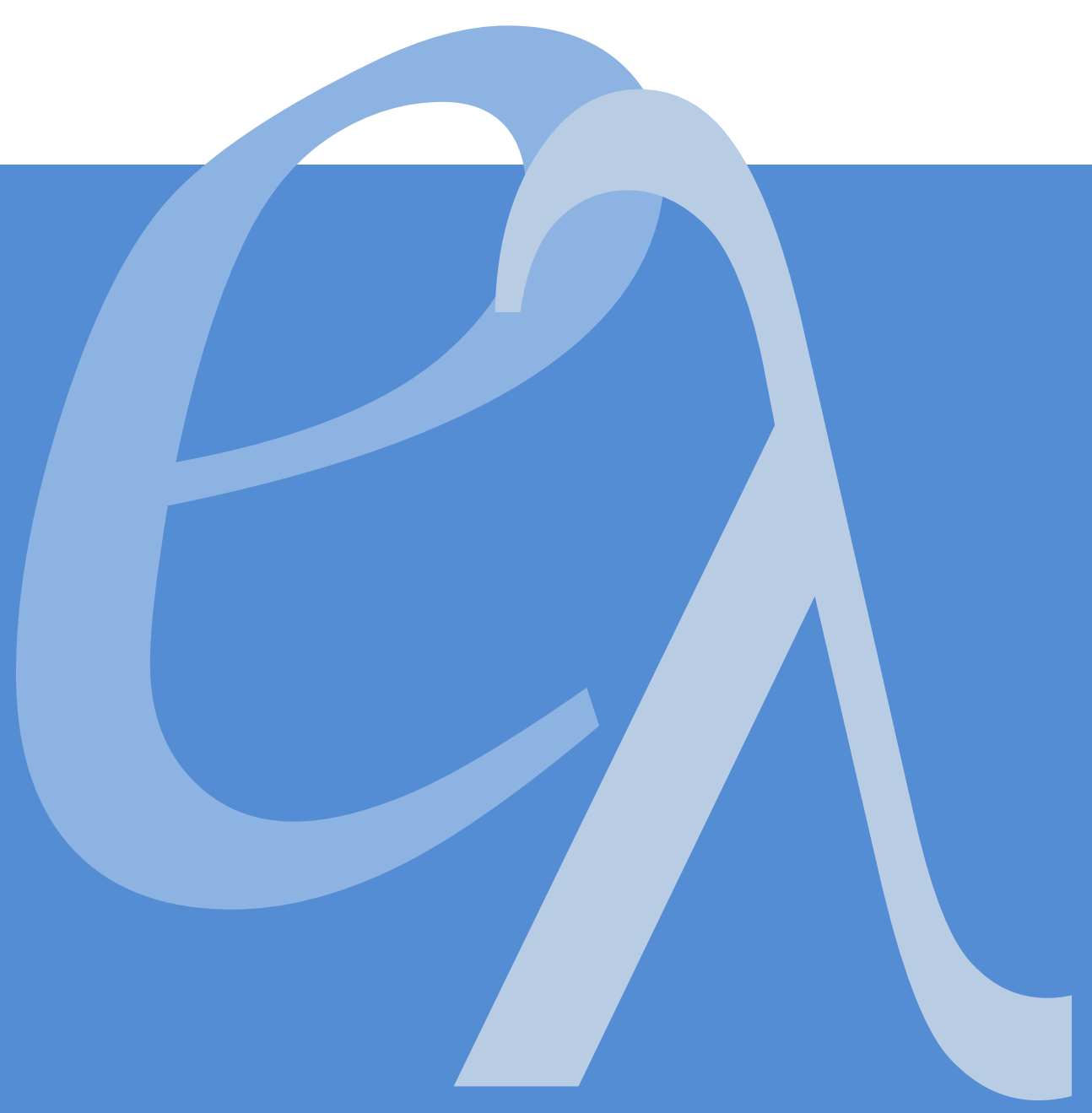




\begin{abstract}
Abstrakt
Záměrem předkládané studie bylo zmapování vývoje jednoho z klíčových témat Platónovy filosofie, problematiky duše, resp. její nesmrtelnosti, která hraje v rámci Platónova vyvíjejícího se konceptu zásadní roli v oblasti ontologické a noetické. Součástí studie není jen reflexe Platónova, ale rovněž názory jeho předchůdců, $\mathrm{z}$ nichž tak či onak čerpá. Pozornost je věnována tradiční homérské představě, zejména pak orfismu a jeho filosofickému uchopení v předsokratovské filosofii. Studie je první částí studie obsáhlejší, která se chce věnovat genesi Platónovy noetiky, kterou jsme uchopili jako cestu od konceptů, jejichž společným jmenovatelem je teorie rozpomínání, k racionálněji založené koncepci vrcholné. Právě předkládanou studií je sledováno základní východisko jeho noetiky, zejména jejích prvních podob.
\end{abstract}




\section{A. Úvod}

Lze tvrdit, že Platónova filosofie je provázaným systémem jako málokterá. Ontologická, noetická a antropologická (potažmo pak i společenská) nauka ze sebe navzájem organicky vyrůstají a navzájem se podmiňují. Ontologie je fundována noetikou a vise versa, antropologický koncept držící mj. Platónovu nauku o jsoucím a jeho noetiku je mikrokosmem jeho pojetí obce (Ústava) apod.

Uvedené tvrzení si dovolujeme přesto, že každý jen trochu obeznámený s Platónovou filosofií ví, že Platónova filosofie se nejen vyvíjí1, ale je mistrem samým rovněž významně kritizována. Je samozřejmě otázkou, jaký celkový smysl má ona autokritika: je opravdu revisí nebo je programovým promýšlením dosud nevysloveného fundamentu založení. ${ }^{2}$ Vývoj pak by byl návratem ke kořenům, „nauce otce Parmenida“3. Lze zjednodušeně říci, že Platónova filosofie stojí de facto na třech, jak jsme již řekli, navzájem se podmiňujících piliřích:

- nauka o jsoucím,

- nauka o poznání,

- nauka o člověku, resp. nauka o duši.

Míra jsoucnosti je Platónovi rovněž mírou poznání. Dokonale poznatelné, resp. dokonalé poznání EPISTEME, GNOME se týká toho, co (dokonale, vpravdě) jest (TO ONTOS ON, resp. TA ONTA), což jsou Platónovy ideje, úplně nepoznatelné (AGNOIA) je nejsoucno (TO ME ON), to co se děje (co jest a není ${ }^{4}$ ), tj. TO GIGNOMENON je pak předmětem mínění (DOXA). Tato spjatost je nejlépe vyjádřena $v$ Ústavě. ${ }^{5} \mathrm{~A}$ konečně: poznání (a tedy jsoucnost) je věcí duše, tedy člověka.

Platónova filosofie je tak provázaným onto-noeticko-antropologicko-etickým (potažmo politickým) konceptem, nelze vykládat Platónovu koncepci idejí ani Platónův koncept poznání, o kterou nám jde v naší následující studii sledující právě vývoj mistrovy koncepce poznání, bez porozumění jeho antropologii. Proto de facto právě jí (což odpovídá ostatně intencím chronologie Platónova duchovního vývoje a jí odpovídající pravděpodobnému vzniku Platónových dialogů) nutně musí odpovídat i sám výklad, jenž rozložíme do dvou studií. První studie se bude tedy týkat Platónova pojetí člověka, resp. (nesmrtelnosti) duše, čímž si vytvoříme základ pro studii druhou, jež se bude zabývat Filosofovou gnoseologií.

První studii rozdělíme do následujících částí: předplatónské pojetí duše, které nám budou representovat tradiční homérské pojetí (B.I.), orfismus (B.II.) a filosofické reflexe presokratiků (B.III). V druhé části se zaměříme na Platónovu nauku o duši. 


\section{B. Předplatónské náboženské a filosofické koncepce.}

\section{B.I. Homér.}

Homér, resp. homérské náboženství nemá to, co bychom mohli nazvat antropologií, tedy tázáním se po tom, co je člověk?

Jisté rozumění tomuto fenomenu lze dedukovat $\mathrm{z}$ homérské eschatologie, tj. z posledních věcí člověka. Pro Homéra platí: smrt je de facto koncem, lidský jedinec zaniká, jeho tělesná schránka je po náležitých obřadech, jak nám Homér sděluje v Iliadě v souvislosti s pohřby dvou velkých hrdinů trojské války, dána zemi. Tento konec však není absolutní, protože něco z člověka přebývá, toto "něco" odchází do Hádovy řiše a přebývá tam nadále. Lze tedy říci, že pozdější psycho-somatiské pojetí lze v náznacích nalézt již u tohoto učitele Řeků. Toto "něco" nazývá Homér PSYCHE a myslí tím ducha zemřelých, někdy EIDOLON ("podobu") zemřelého, "těkavé stíny" atd. Na rozdíl od pozemské podoby PSYCHE schází "PSYCHE jako duchu zemřelých" síla (KIKYS) či život (FRENES).

PSYCHE jako taková znamená Homérovi především život ${ }^{6}$ a zároveň pak jeho projevy. Vedle významu život se $\mathrm{v}$ jednom případě u Homéra objevuje v souvislosti s pojmem PSYCHE význam dech (PSYCHŌ, EIN dosl. dýchám, foukám)7. Tato souvislost se objevuje poté zejména v pozdní antice (vliv židovsko-křest'anské tradice ${ }^{8}$ ). Vedle výrazu PSYCHÉ používá Homér i podobného výrazu THYMOS

PSYCHE odchází podle Homéra do Hádu (to se netýká duše zvírat - THYMOS). Homér říká doslova: „Opravdu tedy v chmurném Hádově domě duše (PSYCHE) a podoba (EIDOLON) jest, jen života (FRENES) v ní není." ${ }^{\prime 9}$

Pokud jde o tělesnou stránku, Homér především nepoužíá pozdější výraz SOMA pro živé tělo je to spíše tělo mrtvé. Nepoužívá ani jiný ekvivalent pro to, co později soma bude. Výrazy, které použivá, jsou: CHROOS - jakýsi obal těla, vnější hranice těla či DEMAS - podoba, lidská postava. Z toho je patrno, že distinkce PSYCHE - SOMA je záležitostí nehomérskou.

Vrat'me se ještě $\mathrm{k}$ vlastní eschatologii. Homér hovoří o odchodu duše do podsvětí. Smrtí je de facto duše (PSYCHE) zbavena veškerých schopností a její podoba (EIDOLON) je vlastně jedinou připomínkou předchozího pozemského života. Tedy cosi takto "vyprázdněného" "přežívá". Toto "vyprázdnění" se děje skrze LETHE -

\footnotetext{
6 Toto v řecké filosofii zůstane základem.

7 Podobně $\mathrm{v}$ češtině duše etymologicky souvisí s dýcháním.

8 Poprvé se objevuje v 5. stol. př.n.l. u Diogenes Apollonie (Bartoš). Podobně jiný "filosof vzduchu" - Anaximenés - téma hýlosoismu - oživlé pralátky, kterou je v obou případech vzduch. Anaximenés doslova říká: „...jako naše duše 'praví' nám vládne jsouc vzduchem.“ Zl. B2 z Aetia, Zlomky s. Zlomky předsokratovských myslitelů, ČSAV, Praha 1962).

9 Il. XXIII. 102 - 104 (Homér, Ílias, Odeon, Praha 1980)
} 
řeku/pramen ${ }^{10}$ zapomnění. Přesto ale Achilleus srovnává, když Odysseovi říká: „raději bych byl sluhou posledního z lidí, než v této zemi králem.“ Tedy ještě cosi zůstává? ${ }^{11}$

Pro nás ovšem platí: návrat po smrti12 z Hádovy řiše není možný. Až na jednu výjimku, kterou je Eurydika - tím se dostáváme k další části našeho pojednání.

\section{B.II. Orfeus a orfismus}

Mýtus o Orfeovi zásadně prolamuje "dosavadní"13 či majoritní14 představu homérskou. Je nepochybné, že tento mýtus vzniká na řecké půdě, jinou otázkou je, z jakých pramenů je napájen, podle všeho jsou to zdroje egyptské ${ }^{15}$, lze uvažovat i o zdrojích východních. Pro civilizace středozemního prostoru, převážně zemědělského charakteru je ostatně myšlenka zmrtvýchvstání typická. Jarní obnova př́rody, znovuzrození nachází své vyjádření $\mathrm{v}$ mnohých mýtech Innana/Ištar, Baal, Persefóne/Demeter aj. Sestup do podsvětí a opětovný návrat zpět ovšem platí jen pro bohy ${ }^{16}$, nikoli pro člověka.

Eurydika je první smrtelnicí, jíž je umožněn návrat zpět. Orfeův sestup není17 pro Homérovu literaturu ničím výjimečný, zato osud jeho milované je precedentem, který otvírá otázku eschatologickou a zároveň vede $\mathrm{k}$ přeinterpretaci PSYCHE a potažmo komposice psycho-somatické.

Je-li homérskou literaturou smrt chápána jako zapomnění (LETHENO), pak se pro orfismus mění role LETHE. Podíváme-li se do orfické literatury - tzv. Zlatých plíšků, můžeme se dočíst následující:

"Toto je dílo Paměti. Když máš zemřít do výstavného Hádova domu, napravo je pramen

u něho se tyčí bílý cypřiš.

Sem sestupují duše (PSYCHAI) zemřelých a osvěžují se chladným douškem (PSYCHONTAI).

10 Zl. desky hovoři o prameni.

11 Cit. Odyss. Je několik vyvolených, kterým v Hádu pamět' zůstává, např. TEIRESIAS, AMFIAROS,

12 Živí sestoupivší do podzemí však odejít mohou. V řec. mýtech jsou zmiňováni: Herakles, Odysseus (možná orfická vložka), Orfeus.

13 Vycházíme $\mathrm{z}$ toho, že Homérova představa je starší, alespoň co se "řecké" půdy týče. Na druhé straně je nezpochybnitelné, že orfická představa representuje starší archaické představy

14 Většinou sdílená představa. U víceméně homérských básníků se objevují některé narážky, které jdou proti Homérově představě konce.

15 Podle Herodóta: „Egypt'ané také jako první vyslovili myšlenku, že lidská duše je nesmrtelná ... Tuto nauku převzali i někteří Řekové, jedni dříve, jiní později, jako by byla jejich vlastní.“ Orfeův sestup do podsvětí ( Výbor z orfických textů, nakl. P. Mervan, Červený Kostelec 2011) s. 65

16 Př́padně pro heroy.

17 KATABASIS EIS HADU 
K tomuto prameni nechod' nikterak blíže!

Dále nalezneš, jak z jezera Paměti

vytéká chladivá voda. Nad ní jsou strážci.

Ti se tě budou se zkoumavým věděním ptát,

co hledáš ve stínu temného Hádu.

Řekni: “Jsem synem Země a hvězdného Nebe.

Jsem vyprahlý žízní a zmírám. Nuže, dejte mi ihned

napít studené vody z jezera Paměti!"

A zeptají se podsvětní královny

a dají ti napít z jezera Paměti,

a jakmile se napiješ, půjdeš i ty po svaté cestě, po níž

kráčejí i jiní slavní zasvěcenci a bakchové.“18

Voda LETHE již není zapomněním, která nechá duši zapomenout na její pozemskou existenci. LETHE především zahlazuje $\mathrm{v}$ duši, která se vrací zpět, vzpomínku na božský svět. Zapomnění není symbolem smrti, ale návratu. Duše, která se napije pramene LETHE, je "odsouzena" pro svou neopatrnost vrátit se zpět19. $Z$ uvedeného rovněž plyne jistá ambivalentnost možnosti návratu. Jde o št'astný osud čili nic. Zlaté plíšky člověka varují před touto možností. Reinkarnace je spíše strastí a utrpením. ${ }^{20}$

Platón přejímající tuto orfickou představu mluví o tom, že duše musí projít deseti inkarnacemi po 3000 letech, aby z tohoto reinkarnačního cyklu definitivně unikla. Nelze tedy z krátkodobého hlediska říci jednoznačně, že možnost návratu je čímsi jednoznačně positivním, spíše naopak. Z dlouhodobé perspektivy je však odpověd' jasná.

Tolik k prvnímu posunu. S nově pochopenou eschatologií duše se mění i její pojetí, resp. zdưraznění její povahy ve smyslu samostatně subsistující substance. Duše přestává být "stínem", tělo pak pouhým obalem. Orfická nauka o duši je zachycena ve Zlomcích předsokratovských myslitelů dvěma zásadními fragmenty, které nám, pravda, přinášejí dva největší Řekové a zvláště u Platóna to může být zpětná projekce jeho představy. V prvním fragmentu se „... ř́íká (orfické vyprávění), že duše vstupuje do těla z vesmíru při vdechování, jsouc nesena větry“ ${ }^{21}$, „Někteří

18 Orfeův sestup ..., s. 75

19 Podobně to vidí Platón, Ústava kn. X.. Pythagoras a Empedokles o sobě tvrdili, že si vzpomínají na své předchozí existence, tzn. uchovali si pamět' i v Hádu.

20 Srovnej s východní představou samsáry (hinduismus, budhismus).

21 Zl. B 11 z Aristotela, Zlomky s. 26 
říkají, že je tělo (SOMA) hrobem (SEMA) duše, tak jako by byla $v$ prrítomné době pohřbena. A ježto duše označuje prostřednictvím těla, cokoliv označuje, i proto je prý tělo správně zváno SEMA (,znak“, „pomník“, „hrob“). A jak se mi zdá, pojmenovali tak tělo zejména Orfeovi stoupenci, domnívajíce se, že duše trpí trest za to, zač je trestána, a že má tuto ohradu jako vězení, aby byla držena ve vazbě (SOZETAI, srvn. SOMA). Je tedy tělo, jak se vskutku jmenuje, vazbou duše, dokud tato nesplatí svou pokutu..." 22

\section{B.III. Předsokratovská filosofie a téma nesmrtelnosti duše}

Téma nesmrtelné duše se objevuje před Platónem (Sokratem) výhradně v návaznosti na orfismus. Prvnímu, u kterého se tato myšlenka zachovala, je myslitel, jehož „posluchačem byl Pythagoras“23, totiž

\section{B.III.a. Ferekydés ze Syru}

Byl řazený k tzv. "sedmnácti mudrcům"24 (Hermippos). Pravděpodobně je jeho nauka napájena prameny orientálními (snad foinickými, ne však egyptskými ${ }^{25}$ ). Zachovaly se nám dva zlomky, ze kterých je patrná Ferekydova představa. „Ferekydés prý počal první učit o stěhování duší.“26 „Ferekydés řekl první, že jsou lidské duše nesmrtelné.“ 27 S tím dále souvisí zpráva Ióna z Chiu: „...duše i po smrti veskrze život radostný má.“ 28

Uvedené nám říká pouze, že nauka o nesmrtelnosti a stěhování duší se v řadě filosofií objevuje v 6. stol. př.n.l. (dle D. L. působí Ferekydés kolem roku 540 př.n.l.) již před Pythagorou, že tato nauka je orientálního původu (Egypt, Fénicie, snad Itálie ${ }^{29}$ ) a pěstovala se zpočátku na italské půdě. ${ }^{30}$ Orfeus není v souvislosti $\mathrm{s}$ Ferekydem zmiňován. V každém případě: Ferekydés odmítl uvedenými tézemi homérskou eschatologii duše.

Známějším representantem konceptu nesmrtelnosti a převtělování duše je

Zl. B 3 z Platóna, Zlomky s. 26

23 Dle Diogena Laertského (dále D.L) I. 15 ( Díogenés Laertios, Životy, názory a výroky proslulých filosofů, Nová tiskárna, Pelhřimov 1995)

24 Ibidem I. 42

25 Egypt'ané: duše nesmrtelná, nabývá různé zvířecí podoby, vypracovanou nauku ale nemají.

26 Zl. A 2 ze Suidy, Zlomky s. 28

27 Ibidem, Zl. A 5 z Cicerona

28 D. L. I. 120

29 Zde je tato nauka v 6. stol. př.n.l. prokazatelná.

30 Orfeus je thráckého původu. Souvislost s Dionýsem - také thrácký původ - zkušenost smrti. 


\section{B.III.b. Pythagoras ze Samu (asi 590 - 500 př.n.1.)}

V souvislosti s Pythagorou Zlomky uvádějí: „Egyptáané vyslovili první toto učení, že je lidská duše nesmrtelná a že při zániku těla vstupuje do živočicha, který se po každé rodí. A když projde všemi suchozemskými, mořskými i okřídlenými zvířaty, vstupuje opět do rodícího se lidského těla a toto její obcházení se děje po tři tisíce let. Tohoto učení užívali někteří Řekové - jedni dříve, druzí později - tak, jako by jim náleželo. Znám sice jejich jména, ale nevypisuji je.“31

Je to vlastně jediná zpráva, kterou nám Zlomky přinášejí. Díogenés Laertský nám přináší přece jen bohatší zprávu:

„První prý též projevil názor, že duše procházejíc kruhem nutnosti se spojuje brzy s těmi, brzy s oněmi živoky. (pozn. - To je pověstná metempsychósa, putování duší, myšlenka původu orientálního, kterou přenesl podle Hérodota Pýthagorás do Itálie z Egypta a kterou převzal od pýthagoriků též Platón.)“32

„Tyto živly se úplně v sebe přeměňují a přecházejí a z nich vzniká vesmír, který je oduševněný, nadaný rozumem ..."33

„Všechny bytosti však nemají duši. Duše je útržek étheru jak teplého, tak i studeného, protože má též účast na étheru studenem. Mezi duší a životem je rozdíl; duše je nesmrtelná, protože i to, od čeho je odtržena, je nesmrtelné. Živé bytosti rodí se navzájem ze semen; zrození ze země je nemožné. Símě pak je kapka mozku...“34

„Lidskou duši rozděluje na tři části: chápavost, rozum a srdnatost. Chápavost a srdnatost mají i ostatní živočichové, rozum však jedině člověk. Sídlo duše se rozprostírá od srdce až po mozek. Její část, která sídlí v srdci, je srdnatost, část sídlící v mozku jsou rozum a chápavost; kapkami z těchto dvou jsou pak smysly. Část rozumná je nesmrtelná; ostatní části jsou smrtelné. Potravu bere duše z krve; jejími vnitřními vztahy jsou větry. (pozn. - Pýthagorás pokládal lidskou duši za část duše světové, tj. za čistý oheň (éther), jako později jeho odpůrce Hérakleitos; proto jest její rozumová, myslící část, kterou nazývá „frenes“, nesmrtelná...) Je neviditelná jak sama, tak její podstata, ježto i éther je neviditelný. Pouty duše jsou žíly, tepny a nervy; když však je při síle a v klidu, stavši se samostatnou, jsou jejími pouty řeči a činy. Když byla vyvržena na zem, bloudí ve vzduchu jako nějaké těleso. Hermés prý je strážcem duší, a proto je nazýván průvodcem, strážcem bran a podzemním, protože přivádí duše odloučené od těl ze země a z moře na jejich místo, a to duše čisté na nejvyšší místo, kdežto nečisté se nesmějí př̌iblížit ani k nim, ani k sobě navzájem, nýbrž jsou spoutány Erínyemi v nezlomných poutech. Celý vzduch je prý 
pln duší; tyto se nazývají daimony a héroy. Ti posílají lidem sny a známky nemoci i zdraví ..."35

Z právě citovaného je nesporné, že:

1) Platón je zastáncem nauky o nesmrtelnosti duše.

2) Tuto nauku čerpá z egyptskou ${ }^{36}$ či orfickou tradicí zprostředkovaných zdrojů.

3) Duši člověka chápe v souvztažnosti s duší světa (kosmu), resp. živlu.

4) Duši, resp. její část (rozum) chápe jako nesmrtelnou.

5) Život duše chápe jako převtělování (PALIGGENESIA 37 , lat. Metempsychosis).

6) Toto převtělování se děje do těl živočichů a opětně do člověka.

7) Má jistou periodicitu - 3000 let. $^{38}$

8) Tato východiska se mu pak projevují v zásadách mravního jednání.

$S$ největší pravděpodobností sdíleli tuto nauku všichni přímí i pozdější mistrovi žáci. Doklad o tom máme však jen u

\section{B.III.c. Alkmaióna z Krotónu (kol. 5 stol. př.n.1.),}

který ovšem tuto chápe $\mathrm{v}$ novém kontextu, který nabude svého významu $\mathrm{u}$ Platóna. Aristotelés totiž uvádí motiv duše, resp. její nesmrtelnosti do souvislosti s pohybem, resp. zdrojem pohybu.

„Alkmeón praví, že je duše nesmrtelná, poněvadž se podobá nesmrtelným bytostem, a to je proto, ježto se věčně pohybuje, nebot' se všechny božské bytosti také bez ustání věčně pohybují, měsíc, slunce, hvězdy i celá obloha.“39

Alkmaion je považován za bezprostředního předchůdce Platóna. Platón je na druhé straně tím, který přiměl Filolaa k prodeji souboru tajných pythagorejských spisů sicilskému tyranu Dionovi ${ }^{40}$. Sám Platón se setkává s jiným významným pythagorejcem Archytou z Tarentu, jemuž dokonce vděčí za svůj život při pobytu na dvoře Dionýsia staršího ${ }^{41}$.

\section{B.III.d. Empedoklés z Akragantu}

Empedoklés je tím, u něhož můžeme orfické vlivy, na rozdíl od Platona, s jistotou prokázat. Důkazy Empedokleova orfismu lze najít $\mathrm{v}$ zachovalých fragmentech orfického titulu Očištění (KATHARMOI).

35 D. L. VIII. 30 - 32

36 R. Hošek uvádí ještě chaldejské a indické prameny (Hošek R., Náboženství antického Řecka, Vyšehrad, Praha 2004)

37 HE PALIGGENSIA - znovuzrození proměnění vzkříšení

38 Uvádí i Platón - Ústava X.

39 Zl. A 12 z Aristotela, Zlomky s. 43-44

40 D. L. VIII. 84

41 Tamtéž VIII. 79 
Přijímá nauku psychosomatiky tak, jak ji chápe orfismus: duše je uvězněna tělem (SEMA ${ }^{42} /$ soma $\left.^{43}\right)$. Tělo Empedoklés pokládá za „... zemi kol člověka...“ ${ }^{44}$, když např. říká „Bohyně duše odívá v šat zcela podivný z masa.“ $45 \mathrm{~V}$ podobném duchu zní: „Do klenuté přišli jsme jeskyně..." 46 Empedoklés, jak vidno, je zřejmě z nejexplicitnějších ${ }^{47}$ autorů před Platónem pojímající člověka jako komposici tělem uvězněné duše.

O nesmrtelnosti duše, resp. o tzv. PALIGGENESII říká: „Vždyt’ jsem byl kdysi hochem a dívkou, keřem i ptákem, rybou též němou z moře se skokem vymrštivší.“ ${ }^{4}$ Zlomek je důkazem nejen Empedokleovy představy převtělování, ale rovněž i faktu, že duši mají i rostliny a zvíratata, tedy vše živé (BIOS). Duše se tedy vtěluje i do zvířat (egyptská představa). Povaha tohoto vtělení je determinována podle Empedokla předchozím vtělením, což Empedoklés vyjadřuje v dochovaném fragmentu:

„Nutnosti je to výrok a prastarý rozsudek bohů,

věčný, kterýžto pevně byl zpečetěn př́isahou mocnou:

,Jestliže v poblouznění poskvrní údy své vraždou,

jestliže hověje sváru kdos vydá přísahu křivou

z oněh démonů, kterým se dlouhého dostalo žití,

po tř́icet tisíc let oni musí blouditi stranou

od blažených a přitom se roditi průběhem času

v rozličných smrtelných tvarech, jež střídají života cesty.

Protože síla vzduchu je nejprve do moře vhání,

moře je na půdu země pak vyplije, země je vrhne

do záře jasného slunce a ono zas do víru vzduchu.

Tak je druh od druha bere a všichni je v nelásce mají.'

Patřím k nim nyní i já, jsa od boha zahnán a bloudě,

ježto jsem běsnému sváru kdysi věřil..."49

42 K výše uvedeným ekvivalentům dodejme: TO SEMA - znamení, mohyla, hřbitov, pečet', rov, odznak.

43 TO SOMA - tělo, mrtvola, osoba, tělesnost, ale také život, celek.

44 Zl. B 148 z Plutarcha, Zlomky s. 81

45 Zl. B 126 z Plutarcha a Porfyria, Zlomky s. 81

$46 \quad$ Zl. B 120 z Porfyria, Zlomky s. 81

47 Podle D. L. „učinil svou básní pythagorejské učení přístupným lidu.“ (D. L. VIII. 55)

$48 \quad$ Zl. B 117 z Diogena a Hyppolyta, Zlomky s. 81

49 Zl. B 115 z Hippolyta aj., Zlomky s. 80-81 
Množství vtělení a jejich povaha je odvislá od správného života a od očištění se od všeho špatného. Duše se podle Empedokla poskvrněním tělesností vzdaluje své božské povahy, očištěním se k ní znovu vrací. Za prohlédnuvšího/očištěného se ostatně Empedoklés sám považoval: „... Já kráčím ne již jako člověk, nýbrž nesmrtelný bůh...“50, „,... nad smrtelníky já vynikám přeubohými.“51 Podle legendy svou božskost dokázal svým skokem do kráteru Etny, jímž měl ukončit svůj život. Podle všeho je Empedoklés nejvýznamnějším hlasatel orfismu, resp. orfické antropologické a etické nauky.

Řekli jsme, že vyvrcholením celé této linie, možná však i tím, kdo tuto linii ex post vlastně fixoval, a je otázkou co z vyloženého jsou jeho vsuvky, je Platón.

\section{Platónova nauka.}

Tím, kdo Platónovi zprostředkoval orfickou nauku, byl pythagoreismus. Ten působí na Platónovu filosofii od počátku druhého období de facto až do konce jeho života, různými náměty a v různé intensitě.

Platónova první cesta na Sicílii má ambivalentní důsledky: neúspěch jeho politické mise je vyvážen obeznámeností s pythagoreismem, který se okamžitě projeví po Platónově návratu a vtiskne se do zásadního dialogu Faidon.

Faidon, psaný pod vlivem ${ }^{52}$ asimilovaného pythagoreismu, je obratem. Faidon nábožensko-filosofickou nauku promění v piliř své filosofie. Nauka o duši je bez nadsázky "Alfou i Omegou" jeho filosofického konceptu druhého a třetího období, péče o toto téma - "péče o duši" (Patočka) je příznačná. Duše drží jeho ontologii, noetiku, etiku i politickou filosofii. Téma duše si představíme v následující struktuře:

I. Duše jako:
a. duše světová,
b. duše lidská.

II. Duše jako:
a. hybatel,
b. nositel poznání.

\footnotetext{
50 část Z1 B 112 z Diogena, tamtéž

51 část Zl B 113 ze Sexta, tamtéž

52 Nemáme dokladu př́mého, že by si nauku o nesmrtelnosti duše osvojil skrze jiné zdroje. Samozřejmě, že podle některých pramenů Platón navštívil Egypt, v Athénách jeho doby byl orfismus znám.
} 
Tím téma určitě zredukujeme a navíc s ohledem na téma našeho pojednání omezíme výklad duše světové (I.a.) na to nejnutnější, s ohledem na připravovanou studii o Platónově teorii poznání bude část (II.b.) vynechána úplně.

Zdůraznění priority duše je dáno Platónovi tím, že je pochopena jako zdroj pohybu, resp. životního pohybu. Platón tímto momentem řeší klíčovou otázku své filosofie, která se mu stále více dere ke slovu. Odkud pohyb, co je to pohyb, popř. jaký je zdroj pohybu. Tento "svět" zde a nyní je podroben pohybu, mění se - na straně jedné a na straně druhé je pouhým obrazem světa neměnného, dokonalého. Tuto věc musel Platón řešit.

Duše jako hybatel se Platónovi ukáže poprvé v dialogu Faidros, kde Platón řeší původ pohybu v oblasti lidské, v pozdním dialogu Timaios pak skrze světovou duši objevuje hybatele Kosmu. Věnujme se nejdříve tomuto tématu. Ač historicky přichází nejdříve řešení na úrovni lidského, začneme "logicky" výkladem duše světové.

\section{C.I.a. Duše světová.}

Svět (KOSMOS) je pochopen jako živý tvor ${ }^{53}$ (živok). Platón tímto svým pochopením světa navazuje na starší tradici přírodní filosofie, jež počíná milétskou filosofií a vrcholí ve filosofii Empedokleově a Anaxagorově. Oba jmenovaní chápou svět jakožto výsledek, jako dualitu látky (živly, resp. částice) působící hybnosti (Láska a Svár, resp. Rozum). V Timaiu se nám objevuje sofistikovanější vyjádření těchto předsokratovských představ. Kosmos je živok, tj. skládá se z těla a oživujícího principu - (světové) duše. Oba komponenty utváří božský demiurgos z různých látek. ${ }^{54}$

"Tělo všehomíra" (KOSMOS) ${ }^{55}$ vzniklo úměrným složením čtyř základních prvků, které byly ve své celosti (nic nenechal mimo kosmos - vložil M.V.) přibrány při budování všehomíra“56. Z toho plyne, že nemůže vzniknout již nic jiného takového ${ }^{57}$, „nýbrž tento svět jest a bude jednorozený “58. Platón doslova ř́ká: "Z této tedy př́ičiny a na základě této úvahy stvořil svět jakožto jeden celek ze všech celých prvků, dokonalý i nestárnoucí a nepodrobený nemocem. Tvar mu dal vhodný a podstatou sourodý. Nebot' živoku, jenž má v sobě objímati všechny živoky, jistě sluší

53 "Tento svět prozřetelností boží stal se živým tvorem, mající duši a rozum.“ Tim. 30 B - C (Platón, Timaios, Kritias, Oikumené,Praha 1996), podobně Politikos 269 D

54 „Pokud jde o přirozenost těl všech živých tvorů, vidíme, že v jejich složení se nachází oheň i

voda, vzduch a zem." Fileb. 29 A Platón, Filebos,Laichter, Praha 1942); Tim 32b - 34b

55 dosl. KOSMEIN znamená řadit KOSMOS je uspořádaný celek. Necháme stranou terminologické různosti.

$56 \operatorname{Tim} 32 \mathrm{C}$

57 tamtéž 33A

58 tamtéž $31 b$ 
takový tvar, který v sobě objímá všechny tvary, co jich jest: proto jej vykroužil v podobě koule, která má všude od středu ke krajům stejné vzdálenosti; tak mu dal tvar ze všech nejdokonalejší a nejjednotnější, uznávaje, že pravidelné je tisíckrát krásnější než nepravidelné. ... mu přidělil pohyb vlastní jeho tělu, ten, který ze sedmera pohybů nejlépe sluší rozumu a myšlení; uvedl jej totiž $v$ otáčivý stejnosměrný pohyb na témže místě kolem vlastní osy, kdežto všech ostatních šestero pohybů mu nedal a způsobil, že jest prost jejich těkání. “59

Tolik $\mathrm{k}$ tělesné složce všehomíra. Pokud jde o druhou část "světové komposice", Platón hovoří následovně: „Tyto tedy všechny myšlenky věčného boha o bohu, který teprve měl kdysi býti, učinily z úplných těl tělo celistvé a úplné, hladké a všude jednotné, se stejnými vzdálenostmi od středu; doprostřed něho pak vložil duši, celým tělem ji rozepjal a ještě zevně jí tělo obalil a tak zbudoval svět jeden jediný, osamělý, kouli v kruhu se otáčející, který může pro svou dokonalost sám se sebou vcházeti ve styk a ničeho druhého nepotřebuje, jsa dostatečně znám i př́telem sobě samému. A tak pro tato všechny věci jej stvořil blaženým bohem. Co se pak týče duše, nevytvořil ji bůh později, jako my ted' počínáme o ní mluviti na druhém místě - vždyt' by nebyl dovolil, aby ve spojeném celku starší bylo pod vládou mladšího to jen my tak mluvíme, kteří se vůbec mnoho řídíme okolnostmi a náhodou, ale on sestavil duši, aby byla přednější než tělo i vznikem i dokonalostí, vynikajíc jako paní a příští vládkyně nad poddaným, a to $z$ těchto prvků a tímto zpơsobem. Ze jsoucna nedělitelného, stále totožného, a $\mathrm{z}$ měnivého jsoucna, obsaženého $\mathrm{v}$ látkách, dělitelného, smísil třetí, střední druh, druh jsoucnosti, účastný podstaty totožnosti a podstaty různosti, a ve stejném poměru jej složil uprostřed jsoucna nedělitelného a tělesného jsoucna dělitelného; pak vzal ty tři prvky a smísil je všechny v jeden útvar, ... Když pak bylo celé složení duše podle vůle tvưrcovy hotovo, budoval potom všechno tělesné uvnitř ní a upevnil jeho střed $\mathrm{k}$ jejímu středu, ona pak od středu až na nejzazší kraj světa všude se rozprostřevši i kolkolem jej zevně obklopivši, sama v sobě se otáčejíc, počala božský počátek nekonečného a rozumového života pro všechny časy. Tedy tělo světa bylo stvořeno viditelné, duše pak sice neviditelná, avšak účastna rozumu i harmonie, nejdokonalejší výtvor tvůrce ze všech pomyslných a věčných jsoucen nejdokonalejšího. “60

Zmiňme ještě třetího "aktéra" tohoto "vesmírného dramatu". „Tvưrce však a otce všehomíra nalézti bylo by trudno. “61 Výše jsme jej nazvali DEMIURGEM, což označuje výrobce, stavitele, řemeslníka. ${ }^{62}$ Nikoli tvưrce v pravém smyslu slova. Je to ten, který netvoří z ničeho (EX NIHILLO) něco, nýbrž skládá dohromady něco již jsoucího. Přestože F. Novotný volí občas tento výraz, nemá na mysli onoho, který „na

62 doslova: ten, kdo vyrábí (ERGON) pro druhé (DEMOS) 
počátku stvořil nebe a zemi...", nýbrž výrobce, který dává dohromady stávající momenty. Rovněž představa osobního výrobce je Platónovi cizí, spíše se zde jedná o personifikaci ideje Dobra, kterou již dříve Platón chápe jako př́ičinu jsoucnosti ${ }^{63}$.

Shrňme: vesmír, všehomír, svět je Platónem pochopen jako živý tvor mající tělo a duši, který v sobě obsahuje všechny živé tvory. Tvưrce/řemeslník "utvořil" obě části živého tvora z různorodých prvků, duši coby oživujícího činitele vpletl do těla světa od středu až po jeho okraj. Podobně jako vložil duši do těla, vložil rozum do duše, takže tento svět má rozumové uspořádání a vedení.

Součástí tohoto "tvořícího" aktu je rovněž stvoření duše lidské. Jestliže duši světa jako celek vytvořil demiurg sám, na výrobě duše lidské se podílel jen u její nesmrtelné části - rozumu, kterou vytvořil ze zbytků látky duše světové. Na výrobě ostatních částí duše lidské se podíleli podřízení bohové.

Co je podstatné z hlediska dalšího výkladu o duši lidské, je následující upřesnění: „Tak pravil a do téhož měsidla, ve kterém byl podle určitého poměru mísil duši všehomíra, nalil zpět zbytky dřívějších látek a mísil skoro týmž způsobem, ale již ne se stejně takovou čistotou, nýbrž o jeden a dva stupně horší. Veškerou pak směs rozdělil na stejný počet duší s hvězdami a přidělil každé hvězdě po jedné; vsadiv je tam jakoby na vůz, ukázal jim přirozenost všehomíra a ohlásil jim zákony osudu: že první vtělení je stanoveno stejné pro všechny, aby nikdo nebyl od něho zkracován, ... pak budou působením nutnosti vsazeny do těla ... kdo dobře prožije příslušný čas, vrátí se zpět do příbytku své př́íbuzné hvězdy a bude míti život blažený a s ní společný; pakliže však neobstojí, promění se při druhém narození v přirozenosti ženy; neustane-li ještě ani v tom stavu od špatnosti, podle toho, čím se proviňoval, promění se podle této vlastnosti pokaždé do takové nějaké zvířecí přirozenosti a ve stálých proměnách nebude dřive zbaven svých útrap, až podřídě se dráze totožnosti a stálosti, kterou má v sobě, rozumem přemůže onen velký a později přirostlý shluk z ohně i vody a vzduchu i země, bouřlivý a nerozumný: pak přijde do svého prvního a nejlepšího stavu.“"64

Z citovaného vyplývají následující korekce předchozích Platonových představ o duši:

- lidské duše, podobně jako duše světová, nejsou věčné. Jejich praeexistence $z$ hlediska jednotlivých inkarnací duše nejde do nekonečna. ${ }^{65}$ Duše má svůj počátek, nemá však svůj konec, alespoň k tomu nic u Platóna neodkazuje.

- lidských duší je omezené množství, jelikož látka, která zbyla po výrobě duše světové, bylo omezené množství. Růst a úbytek populace je dán množstvím inkarnací konstantního počtu duší.

63 Ústava, kn. VI

64 Tim. 41D - 42D

65 REGRESUS AD INFINITUM není Řekům vlastní. 


\section{C.I.b. Lidská duše}

O toto téma nám jde především. Výklad lidské duše přichází "historicky" dřive, logicky však zapadá, resp. je odvozen z obecnějšího výkladu. Ani tento celkovostní výklad není homogenní. Ve Filebu odvozuje Platón duši lidskou přímo z duše světové. $V$ dialogu Timaios jsou duše vytvořeny demiurgem jako samostatné výtvory ze zbytku látky, z níž byla předtím vytvořena duše světová. Vzhledem $\mathrm{k}$ tomu, že šlo o zbytek látky, je demiurgem vytvořen určitý konstantní počet duší, kterých je jako "hvězd na nebi". Nemohou vznikat duše nové ani zanikat stávající. Př́ibytek či úbytek populace je relativní, záleží na momentálním množství inkarnací. 66 Timaiem upravuje Platón otázku, dosud otevřenou, je-li duše věčná? Ani duše světová ani duše lidská nejsou věčné, jsou utvořené. (Na druhé straně jsou však nesmrtelné, nezanikající - viz dále.)

Praexistence duše tedy není absolutní, minimálně jedna inkarnace není reinkarnací. Vlastní inkarnaci nám Platón líčí v d. Faidros veleznámým podobenstvím o duši padající z nebeské klenby vinou jedné ze svých složek smyslnosti. Zde Platón mytho-logicky zdůvodňuje svůj antropologický koncept, když navazuje na dialog Faidon chápající tělo (SOMA) jako hrob, vězení (SEMA) duše, $\mathrm{v}$ němž je duše nedopatřením uvězněna. Etymologické zdůvodnění nám předkládá Platón v dialogu Kratylos: „Někteří tvrdí (o těle (SOMA) - vložil M.V.), že to je hrob (SEMA) duše, jako by v prŕitomné době byla pohřbena ... podle mého zdání dali toto jméno hlavně orfikové, soudíce, že duše trpí trest za věci, pro které je trestána, a že má tělo jako ohradu, aby byla zavřena (SOZETAI) na způsob vězení; a že tedy je tělo docela tak, jak je nazýváno, sOMA (schránkou) duše.“ ${ }^{67}$

Podobně hovoří Platón v d. Gorgias: „Já jsem totiž také už slyšel od kteréhosi z moudrých mužů, že my nyní jsme mrtvi a naše tělo je nám hrobem." $68 \mathrm{~V}$ uvedených citacích se Platón svým pojetím těla odvolává přímo na orfiky a zřejmě na Filolaa. Do třetice dialog Faidon: „... se o tom mluví v tajných řečech zasvěcenců, že my lidé jsme $\mathrm{v}$ jakémsi vězení a že člověk $\mathrm{z}$ něho nesmí se vyprost'ovati ani utíkati.“69 I zde jsou oněmi zasvěcenci míněni orfikové.

Vrat'me se k dialogu Faidros a k druhé stránce lidské komposice, k duši, o níž později Platón říká: „Duše se podstatně liší od těla a v tomto životě je to právě duše, co tvoři bytí každého z nás." 70 Platón nám zde popisuje duši jako obyvatelku božského světa - jde zřejmě o stav před první inkarnací, stav po vlastním utvoření 
duše. ${ }^{71}$ Mythos nám naznačuje, že každá z duší, jež jsou určitého počtu, je osobitým individuálním jsoucnem - substancí72, lišícím se tedy od jiné duše. Tato odlišnost je dána ve Faidru délkou a intenzitou zření idejíi3 v Ústavě přimíšením toho či onoho prvku při vytváření lidí v nitru země. ${ }^{74}$

Přes rozdílnost mají duše jednotnou strukturu, jež je ve Faidru vyjádřena obrazně spřežením dvou koní řízeného vozatajem, kde duše je chápána jako dynamická jednota smyslovosti, srdnatosti a rozumu.

Logika celkového konceptu řeší zákonitě jako první otázku praeexistence duše, z hlediska historického vývoje Platónových názorů byla prioritní otázkou otázka postexistence, resp. otázka eschatologická.75 Naše téma je Sokratem uvedeno především jako téma "smrti" - dialog Faidon. Platón primárně neřeší "prae" nýbrž "post" existenci, to, že jedno podpoří druhé, je věc jiná.

Dialog Faidon je stylizován jako rozloučení s žáky v předvečer Sokratovy zítřejší "smrti" mající podobu rozpravy nad tímto fatálním okamžikem. Platón ústy Sokratovými přichází s myšlenkou"76 pochopení "smrti jako vysvobození", s myšlenkou nesmrtelnosti duše. Viděli jsme, že ani homérovský koncept nemluví o smrti jako o absolutním konci, jistá víra v postexistenci zde byla77 - "cosi" v podsvětí zbaveno všeho trvalo.

Pokud nebudeme mluvit o orfismu, byl homérský koncept již před Platónem narušován různými přístupy evokujícími pozdější koncept Platóna: Pindaros (Olympské zpěvy), Aischylos (Hiketas), Euripides (Prosebnice); o pythagoreismu a Empedokleovi byla řeč výše. F. Novotný mluví o tom, že první Platónovy formulace nauky o nesmrtelnosti duše jsou náboženské povahy, které mistr postupně filosoficky reflektuje, až jim v konečném dává logickou povahu, jejímž výrazem je formulace několika důkazů. ${ }^{78}$ Základními momenty Platónovy nauky, které jsou řešeny ve druhém období, lze shrnout do následujících okruhů:

- trvání duše po smrti člověka,

- posmrtný soud spjatý s odměnou/trestem,

- očišt'ování od vin,

- opětovné vtělování.

Ve třetím období potom přichází téma utvoření duše.

\footnotetext{
71 Později se do tohoto stadia během jednotlivých reinkarnačních cyklů nevrací - viz Ústava X.

72 „jež ke svému bytí nic jiného nepotřebuje“

73 Faidr. 251A

74 blíže viz Ústava III., 414 C

75 Srovnej s Hegelovou korelací historického a logického.

$76 \quad$ F. Nietzsche by dodal adjektivum "NIHILISTICKOU".

77 Z úvahy vyjímáme celou "oblast" božských smrtí (Dionýsos), božské nesmrtelnosti atd. atd.

78 F. Novotný: O Platonovi III., s. 181
} 
Na několika místech Platón poukazuje, otevíraje otázku po trvání duše po smrti člověka, na tehdy rozšířený názor o "zasahování" duší /duchů do života současníků. Ve Faidonu řeší věc razantněji, když se Sokrates zmiňuje, že duše neztrácí smrtí a svým odchodem do Hádu své duševní schopnosti, dokonce může nabýt poznání vyššího než měla ve spojení s tělem. To Platón předpokládá přeinterpretaci osudu duše v Hádu spojenou se zasvěcením a očištěním, které duši umožňují jiný osud ("život s bohy"). ${ }^{79}$ Duše neočištěna (od tělesných sklonů) tíhne po "životu v bahně", který je trestem za život vezdejší, je odsouzena k návratu, k nové inkarnaci. ${ }^{80}$

Toto přesvědčení spíše náboženské povahy je následováno známými třemi důkazy - důkazem pracujícím se vzájemnou střídou vzniku a zániku z opačného ${ }^{81}$, důkaz $\mathrm{z}$ účasti duše na božském - nesmrtelném ${ }^{82}$ a důkaz $\mathrm{z}$ poznání jako rozpomínání83. Faidon znamená zásadní slovo k našemu tématu a řeší výše uvedené dílčí otázky. Platón dokazuje, že duše je nesmrtelná, že nemá konce. Jinou otázkou je, jak je to s její praexistencí, resp. s jejím počátkem?

Přesvědčení o praexistenci duše objevuje Platón již ve Faidonu, kde dokazuje nesmrtelnost duše ANAMNESIÍ. Explicite se toto téma objeví ve Faidrově mýtu o pádu duše a tím oživení těla živoka. ${ }^{84}$

Faidros poprvé uvádí do souvislosti duši jako zdroje pohybu a dokonce na této souvislosti zakládá důkaz. Tím se dostáváme k naší další tematizaci.

\section{C.II.a. Duše jako hybatel}

Souvislost duše a pohybu tušila již předplatónská tradice náboženská (orfismus, pythagoreismus) tak filosofická. Pro Platóna je otázka pohybu otázkou klíčovou. Zopakujme Platónův problém: jsou-li TA GIGNOMENA - proměnlivé entity tohoto světa odrazem oněch TA ONTA dokonalých a tudíž neměnných pravých jsoucen, odkud pohyb?

Otázka po pohybu má dlouhou historii. Je otevřena v plném smyslu slova Parmenidem, který de facto implicite jako první definuje pohyb jako vztah bytí (TO EINAI) a nebytí (TO ME EINAI). Z neexistence nebytí vyplývá Parmenidovi, „že ono jsoucí, jež nevzniklo, nezajde také ... je bez pohnutí." 85

\footnotetext{
79 Př́̌́tí inkarnace.

80 Faidon $80 \mathrm{E}$

81 Faidon 70E - 72A

82 Tamtéž 78B

83 tamtéž 73B - 75E

84 Faidros 246A - 247B a dále (Platón, Faidros, Laichter, Praha 1937)

85 Zl. B7 a 8 ze Sexta, Simplikia aj., Zlomky str. 60
} 
Eleátské popření pohybu vyprovokovalo úvahy o pohybu $\mathrm{v}$ dalším průběhu předsokratovského filosofování. Empedoklés a Anaxagoras jistým zpo̊sobem pohyb připouštějí, ale bez "vpuštění nicoty" coby conditio sine qua non pohybu, nelze pohyb relevantně myslet. Bezesporu posunem je vpuštění nicoty v podobě prázdna (KENON) u Demokrita z Abdér („Jsou atomy a prázdno.“), což má za následek pochopení pohybu jako pohybu fenomenálního či mechanického. Pohyb ontologický bude výsledkem až úvah obou velkých myslitelů klasické řecké filosofie.

Platón tázání po pohybu dědí a navíc má pro něj toto téma zvláštní kouzlo. I pro něj je obtížné explicite připustit nebytí, resp. ideu nebytí. A není-li nebytí a existuje-li "korelace" mezi oběma "světy", pak je otázka po zdroji pohybu, otázkou zásadní.

Objev zdroje pohybu v podobě duše je, jak jsme řekli výše, se uděje v dialogu Faidros. Dejme slovo samotnému Platónovi - Sokratovi: „Veškerá duše je nesmrtelná. Nebot', co se stále pohybuje, je nesmrtelné; co však pohybuje něčím jiným a jest pohybováno od něčeho jiného, to má konec pohybu a tím i konec života. Jediné to, co pohybuje samo sebe, nikdy se nepřestává pohybovat, protože neopouští samo sebe, nýbrž toto jest i všem jiným věcem, které se pohybují, zdrojem a počátkem pohybu. Počátek však je bez vzniku. Nebot' z počátku musí vznikati všechno, co vzniká, ale on sám nevzniká z ničeho; nebot' kdyby počátek z něčeho vznikal, již by to nevznikal počátek. Když pak je bez vzniku, musí být i bez zániku. Vždyt' kdyby zahynul počátek, nikdy ani sám z něčeho nevznikne ani nic jiného z něho, jestliže mají všechny věci vznikati z počátku. Takto tedy je počátkem pohybu to, co pohybuje samo sebe. Toto tedy je počátkem pohybu to, co pohybuje samo sebe. Toto pak nemůže ani zanikati ani vznikati, sice by se musilo veškeré nebe i veškerá země shroutit a zastavit a již by neměly odkud znova dostati pohyb a vznik. Když pak se ukázalo nesmrtelným, co se pohybuje samo od sebe, nebude se ostýchati říci, že právě to je podstata a smysl duše. Nebot' každé tělo, kterému se dostává pohyb zvenku, je bezduché, kterému však zevnitř, samému za sebe, oduševněné, protože toto je přirozená podstata duše; je-li však tomu tak, že není nic jiného, coby pohybovalo samo sebe, než duše, pak je nutně duše jsoucno nevzniklé a nesmrtelné." 86

Citované již ponecháme bez komentáře. Výklad směřujeme $\mathrm{k}$ Platónově noetické koncepci zejména pak oné výchozí, která je založena na teorii rozpomínání. Tato teorie je přímo závislá (zároveň však opačné podmiňuje, jak je patrno z jednoho z Platónových důkazů nesmrtelnosti duše, jenž se nachází v d. Faidon) na koncepci nesmrtelnosti. Nic na tom nemění fakt, že pro pozdější noetiku Platónovy „přímky/úsečky“, nesmrtelnost duše již touto nutnou podmínkou není. V Ústavě, 
kde je „nová“ noetická koncepce vyslovena je naopak nauka o nesmrtelnosti duše dále propracována.

\section{C.II.b. Duše jako nositel poznání}

Tomuto tématu se budeme podrobněji věnovat ve studii následující.

\section{Závěr.}

Pro naše téma, analýza genese Platonovy teorie poznání, bylo zmapování problematiky duše, resp. její nesmrtelnosti conditio sine qua non porozumění minimálně prvním Platónovým noetickým konceptům, jejichž společným jmenovatelem bude ANAMNESIS (u logického konceptu následného již tato problematika nebude mít takovou váhu). Pokusili jsme se stručně zmapovat Platónovy názory a zároveň východiska, z nichž Filosofovy názory vycházely. Zde jsme byli nuceni konstatovat, že zprávy o předchozích tradičních myslitelích tohoto tématu jsou velmi kusé a zpravidla jsou zaznamenávány právě Platónem, což jen podtrhuje ten názor, nejde-li o zpětnou projekci představ samotného mistra, pro něhož právě tradice je důležitým argumentačním nástrojem.

Není sporu o tom, že Řekové jsou dědici staršího majoritního názoru všech tehdejších velkých kultur, cyklického pojetí času, resp. dějin, který vychází z reflexe přírodního cyklu, na němž jsou nejstarší civilisace bytostně závislé. Koncepce nesmrtelnosti duše a s ní spojená koncepce reinkarnační jsou jen jinou vrstvou tohoto obecnějšího konceptu, který svá první vyjádření nachází $\mathrm{v}$ představách náboženských od nejstarších představ sumerských po řecké náboženské představy doby Platónovy. Cyklus můžeme ostatně coby jakýsi základní rys identifikovat u Platóna jak v oblasti kosmologické, tak v oblasti dějinné. Nás tato problematika zajímala zejména sohledem na "erotickou“ koncepci noetickou, jíž se chceme zabývat v naší následující studii. Je nepochybné, že postupné propracování 


\section{Bibliografie}

Platón, Faidros, Laichter, Praha Platón 1937,

Platón, Faidon, Laichter, Praha 1941,

Platón, Gorgias, Laichter, Praha 1932,

Platón, Timaios, Kritias, Oikumené1996,

Platón, Filebos, Laihter, Praha, 1942,

Platón, Ústava, Laichter, Praha 1921,

Platón, Kratylos, Oikumené, Praha 1994,

Platón, Zákony, ČSAV, Praha 1961,

Bartoš. H., Studie k homérskému pojetí lidské psychiky a tělesnosti, E-LOGOS, Praha 2003,

Díogenés Laertios, Životy, názory a výroky proslulých filosofů, Nová tiskárna, Pelhřimov 1995

Elliade M., Dějiny náboženského myšlení II., Oikumené, Praha 1996,

Elliade M., Mýtus o věčném návratu, Oikumené, Praha 2003,

Homér, Ílias, Odeon, Praha 1980,

Homér, Odysseia, Odeon, Praha 1984,

Hošek R., Náboženství antického Řecka, Vyšehrad, Praha 2004,

Diels H., Kranz W., Die Fragmente der Vorsokratiker, Weidmann Dublin/Zurich 1971,

Novotný F., O Platonovi III., Laichter, Praha 1949,

Orfeův sestup do podsvětí (Výbor z orfických textů), Mervan, Červený Kostelec 2011,

Zlomky předsokratovských myslitelů, ČSAV, Praha 1962. 


\section{E-LOGOS}

ELECTRONIC JOURNAL FOR PHILOSOPHY

Ročník/Year: 2011 (vychází průběžně/ published continuously)

Místo vydání/Place of edition: Praha

ISSN 1211-0442

Vydává/Publisher:

Vysoká škola ekonomická v Praze / University of Economics, Prague

nám. W. Churchilla 4

Czech Republic

13067 Praha 3

IČ: 61384399

Web: http://e-logos.vse.cz

Redakce a technické informace/Editorial staff and technical information:

Miroslav Vacura

vacuram@vse.cz

Redakční rada/Board of editors:

Ladislav Benyovszky (FHS UK Praha, Czech Republic)

Ivan Blecha (FF UP Olomouc, Czech Republic)

Martin Hemelík (VŠP Jihlava, Czech Republic)

Angelo Marocco (Pontifical Athenaeum Regina Apostolorum, Rome, Italy)

Jozef Kelemen (FPF SU Opava, Czech Republic)

Daniel Kroupa (ZU Plzeň, Czech Republic)

Vladimír Kvasnička (FIIT STU Bratislava, Slovak Republic)

Jaroslav Novotný (FHS UK Praha, Czech Republic)

Jakub Novotný (VŠP Jihlava, Czech Republic)

Ján Pavlík (editor-in-chief) (VŠE Praha, Czech Republic)

Karel Pstružina (VŠE Praha, Czech Republic)

Miroslav Vacura (executive editor) (VŠE Praha, Czech Republic) 